\title{
Review
}

\section{Therapeutic Potential of Plants as Anti-microbials for Drug Discovery}

\section{Ramar Perumal Samy and Ponnampalam Gopalakrishnakone}

\author{
Venom and Toxin Research Programme, Department of Anatomy, Yong Loo Lin School of Medicine, \\ National University of Singapore, Singapore - 117597
}

\begin{abstract}
The uses of traditional medicinal plants for primary health care have steadily increased worldwide in recent years. Scientists are in search of new phytochemicals that could be developed as useful anti-microbials for treatment of infectious diseases. Currently, out of $80 \%$ of pharmaceuticals derived from plants, very few are now being used as anti-microbials. Plants are rich in a wide variety of secondary metabolites that have found anti-microbial properties. This review highlights the current status of traditional medicine, its contribution to modern medicine, recent trends in the evaluation of anti-microbials with a special emphasis upon some tribal medicine, in vitro and in vivo experimental design for screening, and therapeutic efficacy in safety and human clinical trails for commercial outlet. Many of these commercially available compounds are crude preparations administered without performing human clinical trials. Recent methods are useful to standardize the extraction for scientific investigation of new phytochemicals and anti-microbials of traditionally used plants. It is concluded that once the local ethnomedical preparations of traditional sources are scientifically evaluated before dispensing they should replace existing drugs commonly used for the therapeutic treatment of infection. This method should be put into practice for future investigations in the field of ethnopharmacology, phytochemistry, ethnobotany and other biological fields for drug discovery.
\end{abstract}

Keywords: ethnopharmacology - human clinical trails - phytochemicals - secondary metabolites - traditional medicine

\section{Introduction}

Primitive people have used plants to cure a variety of human ailments. Even today, $85 \%$ of Indians use higher plants as effective anti-microbials for the treatment of various diseases (1). A large number of anti-microbial agents derived from traditional medicinal plants are available for treating various diseases caused by microorganisms (2). They are used to eliminate the infecting micro-organisms. The therapeutically useful novel agents

For reprints and all correspondence: Prof. P. Gopalakrishnakone, Venom and Toxin Research Programme, Department of Anatomy,

Yong Loo Lin School of Medicine, MD 10, 4 Medical Drive, National

University of Singapore, Singapore - 117597. Tel: + 65 - 65163207;

Fax: + 65 - 67787643; E-mail: antgopal@nus.edu.sg should inhibit the germs and exhibit greater selective toxicity towards the infecting germ than the host cells (3). The mode of action for plant-derived agent should target biochemical features of the invading pathogens that are not possessed by the normal host cell. Some of the factors important for anti-microbial treatment include methods such as sensitivity of the infecting micro-organism to a particular agent (4). Side-effects of the plant-derived agent can be tested relative to direct toxicity upon animal cells because of their close association with human tissues or cells. So, we attempt to summarize information linked to plant extracts/chemical substances for the effective treatment of certain bacterial and fungal diseases. We also discuss the obvious necessity for new anti-microbial agents in various therapy regimens. 

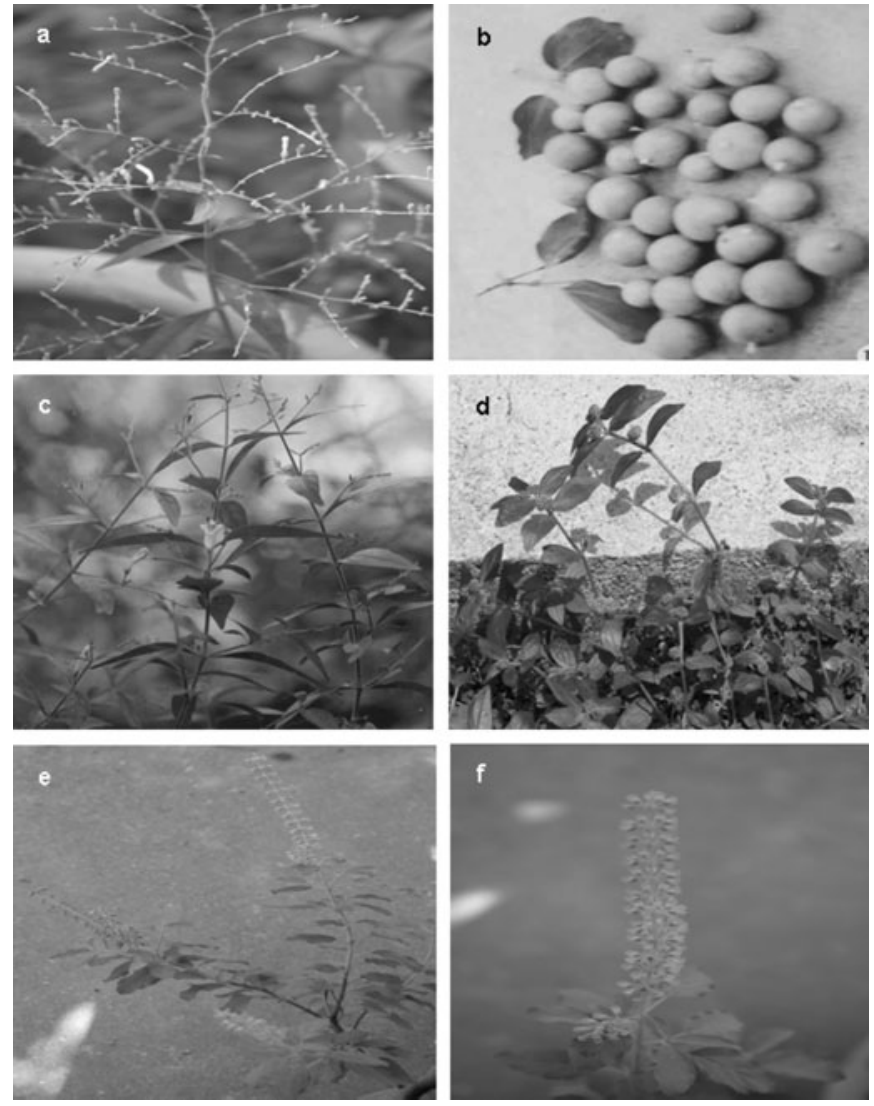

Figure 1. Some of the folk medicinal plants and its various parts used as therapeutic potential in Southern Tamil nadu, Western Ghats of India. (a and c) Seed with flower of Andrographics paniculata Wallichi ex Nees (Acanthaceae), (b) fruit of Strychnos nux-vomica L. (Loganiaceae), (d) Euphorbia hirta L. (Euphorbiaceae), (e) whole plant of Ocimum sanctum L. (Lamiaceae) and (f) inflorescence of Ocimum sanctum L.

\section{Recent Trends in the Evaluation of Anti-microbials}

Anti-bacterial screening of traditional medicinal plants has been the source of innumerable therapeutic agents (Figs 1 and 2). In the area of antibiotics, random screening as a tool of discovering new biologically active molecules has been most productive. Chemotaxonomic considerations and target-directed screening also play a crucial role. For a successful outcome the main requirement is access to a large number of compounds/extracts that must be well screened (5). Ethanol extracts of 78 traditional medicinal plants from India are used for treating infectious diseases and show bacterial and fungal activity at $1.6 \mathrm{mg} / \mathrm{ml} \mathrm{(6)}$. The $50 \%$ ethanol extracts of 285 plant materials were screened for 61 biological activities and revealed effective anti-bacterial, and a wide range of pharmacological, activities (7). Antimicrobial and phytochemical studies revealed 45 Indian medicinal plants effective against multi-drug- resistant bacteria (8). These results suggest the presence of either good anti-bacterial potency or the high concentration of an active principle in the extract. Plant extracts were
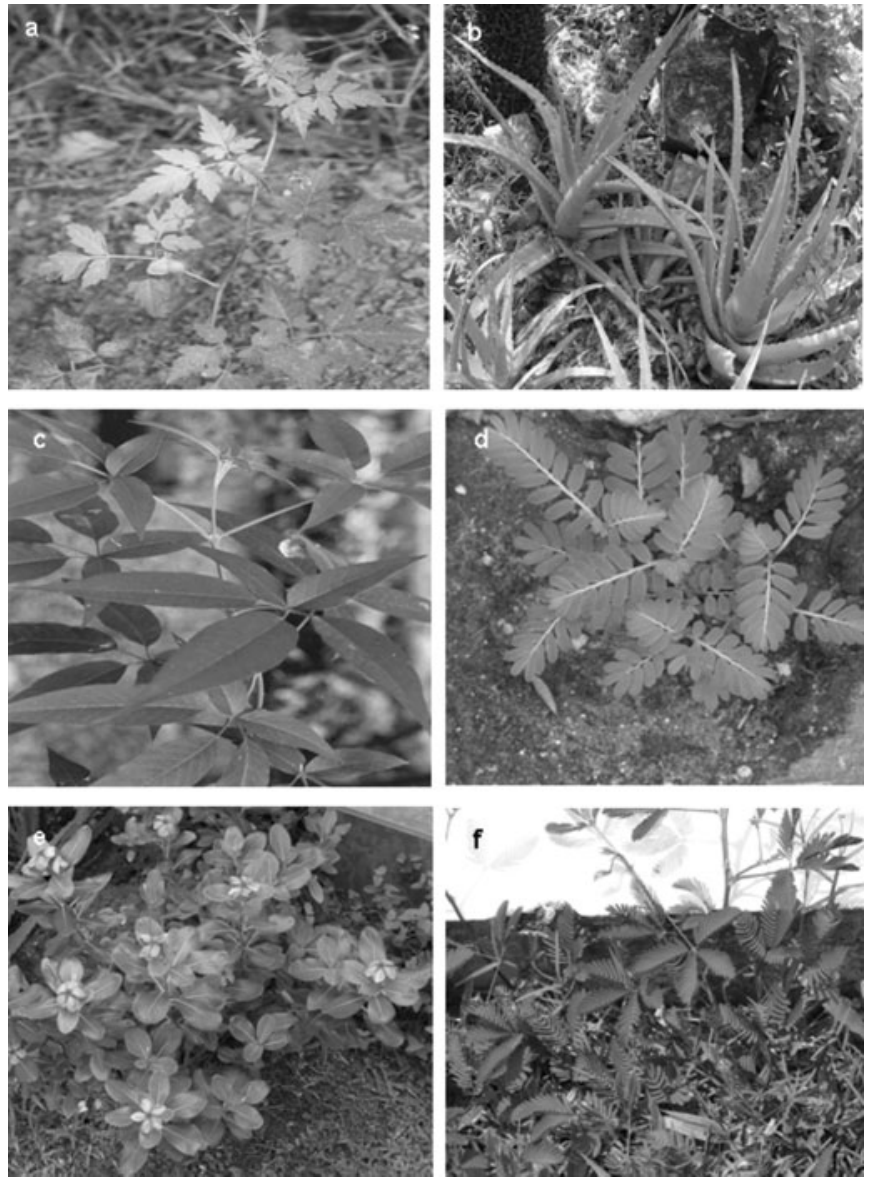

Figure 2. Some of the folk medicinal plants and its various parts used as therapeutic potential in Southern Tamil nadu, Western Ghats of India. (a) Cardiospermum halicaccabum L. (Sapindaceae), (b) Aloe vera Mill. (Liliaceae), (c) Vitex negundo L. (Verbenaceae), (d) Phyllanthus amarus (Euphorbiaceae) (e) Cathranthus roseus (L) and (f) Mimosa pudica L. (Mimosaceae).

screened phytochemically and $20 \%$ of the species yielded positive reactions for alkaloids, $25 \%$ species contained steroids/triterpenoids and $45 \%$ of species possessed saponins (9). Those plants with anti-bacterial effects are rich in polyphenolic substances such as tannins, catechins, alkaloids, steriods and polyphenolic acids. The anti-bacterial activity also could be due to various chemical components and the presence of essential oils in adequate concentrations, which damage microorganisms (10). The insolubility of essential oils and nonpolar extracts make it very difficult for them to be used in an aqueous medium during the study of anti-microbial activity (4). A great number of factors can influence the results such as the extraction method, volume of media, culture composition and incubation temperature. However, the recent advanced method of bioautographic TLC assays makes it possible to localize antimicrobial activity on a chromatogram (11); while bioassay-guided fractions led to the isolation of compounds (12). 


\section{Anti-microbial Compounds from Plants}

Traditional medicinal plants have an almost maximum ability to synthesize aromatic substances, most of which are phenols or their oxygen-substituted derivatives (13). Most of these are secondary metabolites, of which 12000 plant-derived agents have been isolated in the recent past. Many of these substances serve as plant defense mechanisms against invasion by micro-organisms (Table 1), insects and herbivores. Some of the plant substances such as terpenoids are responsible for odor (quinones and tannins) plus pigment of the plant. Many compounds are responsible for plant flavor (e.g. the terpenoid capsaicin from chili peppers), and some of the same herbs and spices used by humans to season food yield useful medicinal compounds. The useful major groups of antimicrobial phytochemicals can be divided into several categories that include alkaloids, flavones (flavonoids, flavonols, Quinones), essential oils, lectins, polypeptides, phenolics, polyphenols, tannins and terpenoids.

\section{Alkaloids}

Heterocylic nitrogen compounds are called alkaloids. The first medically useful alkaloid was morphine, isolated in 1805 from Paver somniferum (opium poppy) (27). The name morphine comes form the Greek word Morpheus, which means 'god of dreams'. Codeine and heroin are both derivatives of morphine. Diterpenoid alkaloids, isolated from the plants of the Ranunculaceae family, are commonly found to have anti-microbial properties. Bioassay-guided isolation studies done on the root extract of Polyalthia longifolia shows that it possesses significant anti-bacterial activity led to the isolation of three new alkaloids pendulamine $\mathrm{A}$, pendulamine $\mathrm{B}$ and penduline along with stigmasterol 3-O-beta-D-glucoside, allantoin, the known diterpenoid kolavenic acid and the azafluorene alkaloid isoursuline. Compound pendulamine $\mathrm{A}$ and pendulamine B were found to be active. Micro-organism inhibition concentrations, abbreviated as MICs, are $\sim 0.02-20 \mu \mathrm{g}$ against bacteria (12). The seed pods of Erythrina latissima yielded erysotrine, erysodine, syringaresinol, vanillic acid and a new erythrina alkaloid, (+)-10,11-dioxoerysotrine that was lethal to brine shrimp. 2-(5'-Hydroxy-3'-methoxy phenyl)-6-hydroxy5 -methoxybenzofuran has strong anti-microbial activity against yeast spores (28). Ethanol extracts of the Guatteria multivenia root have furnished known alkaloids such as liriodenine, lysicamine, lanuginosine, guadiscine and $O$-methylpallidine. Lanuginosine possesses weak inhibitory effects against fungi and liriodenine was found to have anti-microbial activity against both bacteria and Candida albicans (29). Pyrrolizidine alkaloids (Heliotropium subulatum) extracts showed antimicrobial activity against both fungal and bacterial species (3). Alkaloids isolated (Schizozygia coffaeoides) using bioassay-guided fractionation was isoschizogaline, schizogynine and indoline that were subsequently shown to be the most active anti-fungal compounds (30). The anti-microbial berberine alkaloid isolated from Mahonia aquifolium was active against bacteria (31). For the antimicrobial components of berberin from Hydrastis canadensis, change in the lipophilicity of protoberberinium salts caused by modification of the substituents appears to influence the anti-bacterial activity. Both berberine and palmatine exhibited the greatest anti-bacterial activity (32). Biologically active carbazole alkaloids (from Murraya koenigii) showed mosquitocidal and anti-microbial activites, as well as exhibited topoisomerase I and II inhibition activities (33).

\section{Flavones, Flavonoids and Flavonols}

Flavones are phenolic structures containing one carbonyl group. They are hydroxlated phenolic substances that occur as C6-C3 units linked to an aromatic ring. Flavonoids are known to be synthesized by plants in response to microbial infection (34) and are effective antimicrobial substances against a wide array of microorganisms. Anti-microbial flavonoids have been reported from E. latissima (28). Dimethoxyflavone and bonducellin were isolated from the aerial parts of Caesalpinia pulcherrima. Isobonducellin was found to be a homoisoflavanoid containing a cis (Z)-double bond possessing anti-microbial activity (35). Compounds of C. pulcherrima with anti-viral activities were derived from the flavonoid of quercetin (36). Moreover, the flavonoids, acacetin-7-o- $\beta$-D-galactopyranoside of $C$. morifolium was found to be active as towards HIV (37). A wide variety of flavonoids, sesquiterpenoid alcohols, triterpenoids and quinic acid caffeates product from plants may also be useful as anti-microbials (38). The activity is probably due to their ability to form a complex with extra-cellular and soluble proteins, which then binds to bacterial cell wall. More lipophilic flavonoids may also disrupt microbial membranes (39). Flavonoids lacking hydroxyl groups on their $\beta$-rings are more active against microorganisms and the microbial target is the membrane with -OH groups (40).

\section{Essential Oils and Terpenoids}

The anti-microbial properties of aromatic volatile oils from medicinal, as well as other edible, plants have been recognized since antiquity. Essential oil, which is used as a food flavoring agent, possesses a broad spectrum of anti-microbial activities attributed to the high content of phenolic derivatives such as carvacrol and thymol. Some essential oils are used for systemic and superficial fungal infections and further exploration reveals a broad spectrum effect against other pathogenic manifestations that include malignancy (41). Moreover, fragrance of 


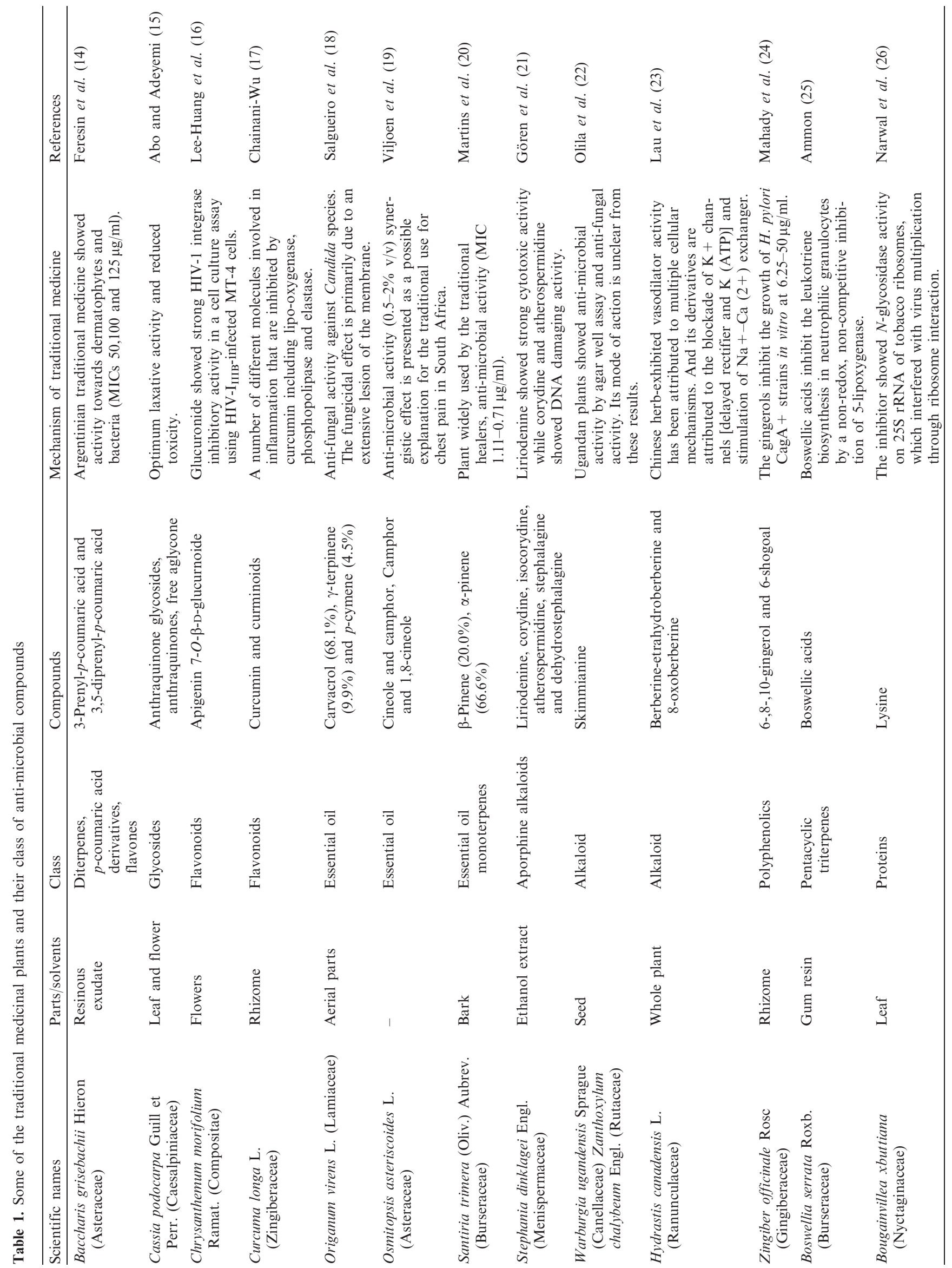


plants is associated with essential oils. This oil consists of secondary metabolities which are highly enriched in compounds based on an isoprene structure. They are called terpenes and occur as diterpenes, triterpenes, tetraterpenes as well as hemiterpenes and sesquiterpenes. When the compounds contain additional elements, usually oxygen, they are termed as terpenes. Terpenenes or terpenoids are active against bacteria (29). Nearly $60 \%$ of all essential oil derivatives possess inhibitory effects upon fungi while $39 \%$ inhibited bacteria (40). The seeds of Nigella sativa Linn. (Ranunculaceae) contain active constituents, e.g. volatile oil and thymoquinone showed protection against nephrotoxicity and hepatotoxicity induced by either disease or chemicals. The seed oil has anti-inflammatory, analgesic, anti-pyretic, anti-microbial and anti-neoplastic activity (42). Petroleum ether extract of Melicope indica afforded two unusual pentacyclic triterpenes and the ubiquitous steroids, stigmasterol and sitosterol (43). Pentacyclic tritepenes were isolated from Combretum imberbe that are novel glycosidic derivatives (hydroxyimberbic acid). Terminalia stuhlmannii Engl. stem bark yielded two glycosides of hydroxyimberbic acid, several of which had anti-bacterial activity. Imberbic acid showed potent activity against Mycobacterium fortuitum and Staphylococcus aureus (44). New cycloartane-type triterpenes isolated from the aerial parts of Acalypha communis exhibited moderate anti-microbial activity (MIC 8 and $32 \mu \mathrm{g} / \mathrm{ml}$ ) against vancomycin-resistant enterococci. Compounds tested in an in vivo model did not provide protection to mice infected with $S$. aureus (45). Friedelin, epifriedelinol, $\beta$-amyrin, $\beta$-sitosterol, $\beta$-sitosterol 3- $\beta$-Dglucopyranoside and naringin isolated from the methanol extract of dried rhizome from Drynaria quercifolia showed concentration-dependent broad spectrum of anti-bacterial activity (46). Andrographolide, neoandrographolide and andrographiside (Fig. 1) are the diterpene lactone of Andrographis paniculata (king of bitter) possesses liver protection under various experimental conditions (47). It showed weak anti-microbial activity against bacteria and viruses. Asiaticoide and hypaphorine (Fig. 1) are the mixture of pentacyclic triterpene of Centella asiatica. Topical and oral applications of asiaticoside improved wound healing in guinea pigs (1 mg/kg dose) (48). Tinosporaside and columbin are diterpenes and cordifolioside (Fig. 1) is a sesquiterpene glucoside of Tinospora cordifolia as reported (49). An ether extract of the aerial part of $T$. cordifolia inhibited the growth of $M$. tuberculosis at 1:50000 dilutions (50). The mechanism of action of terpenes is not fully understood but it is speculated to involve membrane disruption by the lipophilic compounds.

\section{Lectins and Polypeptides}

The active compounds can be grouped into two major classes: anti-microbial proteins and a wide variety of nonprotein compounds. Their distribution is often tissue specific (51) and they are usually found in cells located at the external layers of plant tissues, thus suggesting that these compounds would be the first line of defense against a pathogen attack. An anti-microbial compound of $316 \mathrm{Da}$, present in the soluble fraction of strawberry (Fragaria ananassa) leaves shows in vitro activity against bacterial and fungal plant pathogens (52). An antimicrobial protein (WjAMP-1) purified from leaves of Wasabia japonica showed anti-microbial activity against both fungi and bacteria (53). Oleanolic acid (C. paraguariensis Burk, Fabaceae) from an Argentinean legume was found active against Bacillus subtilis and $S$. aureus with MICs $64 \mu \mathrm{g} / \mathrm{ml}$ (54). Peptides that are inhibitory to micro-organisms were first reported in 1942. Peptides called cathelicidins represent an important native component of innate host defense in mice and provide protection against necrotic skin infection caused by Streptococcus (55). They are often positively charged and contain disulfide bonds (56). The mechanism of action may be ion channel formation in the microbial membrane or competitive inhibition of adhesion of microbial proteins to host polysaccharide receptors (57). Diverse application has been demonstrated for antimicrobial peptides as anti-infective agents. The broad spectrum activity displayed by anti-microbial peptides is considered a 'chemical condom' against HIV infection and Herpes simplex virus (58).

\section{Polyphenols and Phenolics}

Some of the simplest bioactive phytochemicals consist of a single substituted phenolic ring. Cinnamic and caffeic acids are common representatives of a wide group of phenylpropane-derived compounds that are in the highest oxidation state. The common traditional medicinal plants have such compounds that are effective against bacteria (59). Phenolic compounds possessing a C3 side chain at a lower level of oxidation and containing no oxygen are classified as an essential oil and reported as antimicrobials. Coumarins are phenolic substances made of fused benzene and $\alpha$-pyrone rings (60). Several coumarins have anti-microbial properties and anti-viral effects reported in 1954 (61). Anti-microbial properties of phenolic compounds (Finnish berries) active against pathogenic bacteria exhibited different sensitivities towards phenolics. These properties can be utilized in functional food development and for food preservation (62). Phenols are toxic to mico-organisms because of the sites and numbers of hydroxyl groups on the phenol groups, which is all related to their relative toxicity of micro-organism. There is evidence that highly oxidized phenols possess more inhibitory action (63). The mechanism responsible for phenolic toxicity to micro-organisms includes enzyme inhibition by the oxidized compounds, possibly through reaction with sulfydryl groups or through more non-specific interactions with proteins (64). 
Polyphenols which can form heavy soluble complexes with proteins may bind to bacterial adhesions thereby disturbing the availability of receptor on the cell surface.

\section{Tannins}

Tannins are generally descriptive of a group of polymeric phenolic substances capable of tanning leather or precipitating gelatin from solutions, the property known as astringency. Their molecular weights range from 500 to $3000 \mathrm{Da}(55)$ and are found in almost every plant parts: bark, leaf, root, wood and fruit. They form two groups, hydrolysable and condensed tannins based on gallic acid. The first group is usually found as multiple esters with D-glucose, while the more numerous condensed tannins are derived from flavonoid monomers. Tannins (tannic acid) are water-soluble polyphenols that are present in many plant foods (65). Polyphenols (Tea) and many tannin components have been suggested to be anti-carcinogenic. The anti-microbial activities of tannins are well documented. The growth of many fungi, yeasts, bacteria and viruses were inhibited by tannins. Tannic acid and propyl gallate inhibit food borne, aquatic and off-flavor-producing micro-organisms. Their antimicrobial properties seemed to be associated with the hydrolysis of an ester linkage between gallic acid and polyols hydrolyzed after the ripening of many edible fruits. Tannins in these fruits thus serve as a natural defense mechanism against microbial infections. The antimicrobial property of tannic acid can also be used in food processing to increase the shelf-life of certain foods, such as catfish fillets. Tannin components of epicatechin and catechin (Vaccinium vitis-idaea L.) showed strong anti-microbial activity against bacteria and fungi. Such anti-microbial activity could potentially be used as a possible alternative for the treatment of periodontal diseases (66). Eucaglobulin is a new complex of gallotannin and monoterpene of leaves of Eucalyptus globulus possessing anti-bacterial effects (67). Methanol extracts of $T$. citrina fruit yielded known tannins such as corilagin, punicalagin and chebulagic acid that were tested for anti-microbial action (68). Arjunolic acid, ethyl gallate, flavone, ellagic acid and gallic acid are the active constituents of $T$. arjuna (Fig. 1). Macrocyclic structures of bioactive ellagiannins (gluconic acid core) and oligomeric ellagitannins have been found in species of Myrtaceae and Elaeagnaceae and they too possess anti-bacterial activity against Helicobacter pylori (69). Proanthocyanidins (condensed tannins) and hydrolyzable tannins are the two major classes of tannins. Proanthocyanidins are flavonoid polymers, the most common type of tannin found in forage legumes (70). Hydrolyzable tannins are polymers of gallic and ellagic acid esterified to a core molecule of Phyllanthus emblica (Fig. 1). Phyllanthin and hypophyllanthin are lignans of $P$. niruri (Fig. 1) that enhance cytotoxic response against multi-drug-resistant cells (71). The mode of anti-microbial action of tannins and their ability to inactivate microbial adhesins, enzymes and cell envelop transport proteins also have been studied.

\section{Mixtures}

The neem (Azadirachta indica), verasingam pattai (Zanthoxylum limonella), Indian babool (Acacia nilotica) stick are widely used as tooth brushes by various tribes throughout India, Africa and Nigeria. The neem ( $A$. indica), traditionally used as medicine, and in particular the stem bark extract showed activity against various Candida species. The minimum fungicidal concentrations ranged from 0.06 to $>8 \mathrm{mg} / \mathrm{ml}$ (72). Antibacterial effects of neem mouthwash have been tested over a period of 2 months against salivary levels of Streptococcus mutans, Lactobacillus species and $S$. mutans. They were all inhibited by neem-based mouth washes (73). The active component of the Nigerian chewing stick (Fagara zanthoxyloides) was found to consist of various alkaloids (74). Ayurvedic practitioners rely on plant extracts, both single and mixed combination, for the preparation. The preparations are used to treat a wide range of human, as well as animal, ailments (75). Cleistanthus collinus is known as oduvanthalai (Nillipalai) in India and all parts of this plant are highly poisonous. Various extracts of this plant yield a multitude of compounds that include glycosides, arylnathalene lignan lactones such as cleistanthin A and $\mathrm{B}$, collinusin and oduvin found to have anti-microbial activities (76). Strawberry extracts were strong inhibitors of Salmonella bacteria. The dried flower-heads of Chrysanthemum moriforium are an oriental drug as well as a popular herbal tea in China, which has been used for the treatment of eye diseases in Japan. They have been found to possess anti-bacterial, anti-fungal, anti-viral and anti-inflammatory activities (77).

\section{Experimental Designs for Extraction}

Traditional healers prepare a wide range of healing juices, crude extracts, paste and tincture from various herbs by using a water extract. Water or alcohol (methanol/ ethanol) are mainly used for a large number of crude extract/library preparations (dry powder soaking or suspension, mechanical shaker, distillation of essential oils), sequential grinding (alkaloids, steroids, triterpenoids), gradial centrifugation (lectins and polypeptides) and acid hydrolysis (phenols) for a specific time frame. A variety of extractants are used for their ability to solubilize anti-microbials and also other factors from plants. This particular study provided a more standardized extraction method for a wide variety of plants (78). The crude extracts or mixtures of compound-rich residues 
are used for the initial screening of plants for antimicrobial activities. In many reports, methanol or ethanol are used for alkaloid extraction; acetone for flavonoids and steroids, hexane, diethyl ether and chloroform for fat soluble oils, wax, lipids and esters; dichloromethane for terpenoids, ethyl acetate for esters, ethanol for sterols, polyphenols, tannins and water for the water soluble components like glycosides, polysaccharides, polypeptides and lectins, which are most effective against pathogens. TLC, other chromatography separations (79) and several solvent systems are used for the elution of enormous water and organic solvent (Fig. 3) soluble anti-microbial compounds (Table 2). Diverse analytical spectral devices are often used for the identification and structural characterization of active components from plants (Fig. 4). However, the water medium is the most suitable for the treatment point of view in humans/animals.

\section{Efficacy for In vitro Studies}

Several plants used for the treatment of various infections have some in vitro activity against pathogenic Grampositive bacteria. In our findings, the popular use of Tragia involucrata as a traditional medicine for the treatment of scabies and skin infection was documented in India. The most promising $T$. involucrata and its extracts (organic and water) exhibited marked and/or broad spectrum activity especially towards Gramnegative and -positive bacteria. These results suggested the presence of good anti-microbial potency and a high concentration of active principles that were proven useful for wound healing in a rat model. Anti-inflammatory properties and safety of extracts were also evaluated. Effective inhibition is due to the high content of active principles in the extract. Whereas, among catechins (a constituent of green tea) and pyrogallol (Holmskioldia sanguinea Retz) (89), as well as other anti-fungal compounds like ginger (Zingiber officinale Roscoe) were found active against human pathogens (90). The use of natural remedies for the treatment of viral diseases has a long history in traditional systems of medicines. An extract of Ribes nigram has been used as an ingredient in a variety of food and folk medicines in Japan. The extract has activity which inhibits virus replication in cells, due to the inhibition of protein synthesis among infected cells from the very early stage of infection (91). Anti-protozoal and cytotoxic activities were also reported (92).

\section{Need to Explore New Anti-microbials}

This review highlights some of the important medicinal plants used for traditional medicine and the medicinal information was obtained from various traditional healers or medical practitioners in the Hilly areas in
India. Tribal healers in most countries, where traditional ethnomedical treatment is frequently used, provide instructions to local people as how to prepare medicine from the plants (93). They keep no records and the information is mainly passed on verbally from generation to generation (94). World Health Organization (WHO) has shown great interest in documenting the use of medicinal plants from tribes in different parts of the world (95). Many developing countries have intensified their efforts in documenting the ethnomedical data on medicinal plants. Moreover, an unexplored reservoir of phytochemical information is being rapidly destroyed by deforestation. About $10-20 \%$ of all plant species become extinct and above all, there is a continuing threat and pressure upon the existing plants by fast-growing industrialization and commercial exploitation of pharmaceutical industry (96). However, the medicinal plants are an important health resource in all the regions of India and particularly among the primitive communities (97). Though a vast number of plants have not been studied for their anti-microbial properties these may become new sources of plants for anti-microbial activity. There is a need for further collaborative biological screening of plant extracts in single, or combination, form. Phytochemicals derived from plant products are quite effective in controlling the growth of micro-organism. The recent approaches of bioautography assay (11) and high-throughput screening methods are the most suitable method to detect the anti-microbial component present in the extract. With the current trend on increasing awareness in traditional medicine, the plant-derived agents have been attracting much interest as natural alternatives to synthetic compounds because microbes slowly develop resistance against antibiotics. Scientists are trying to tap the pharmaceutical and food values of these many unidentified plants. It is believed that the plants (traditional medicine) will be a major source of new chemicals and raw materials for the pharmaceutical industry.

\section{Conclusions}

From the above studies, it is concluded that the traditional plants may represent new sources of antimicrobials with stable, biologically active components that can establish a scientific base for the use of plants in modern medicine. These local ethnomedical preparations and prescriptions of plant sources should be scientifically evaluated and then disseminated properly. The knowledge that primitive people used plants gives a clear idea about the unclear botanical preparation of traditional sources of medicinal plants. These can be extended for future investigation into the field of pharmacology, phytochemistry, ethnobotany and other biological actions for drug discovery. 


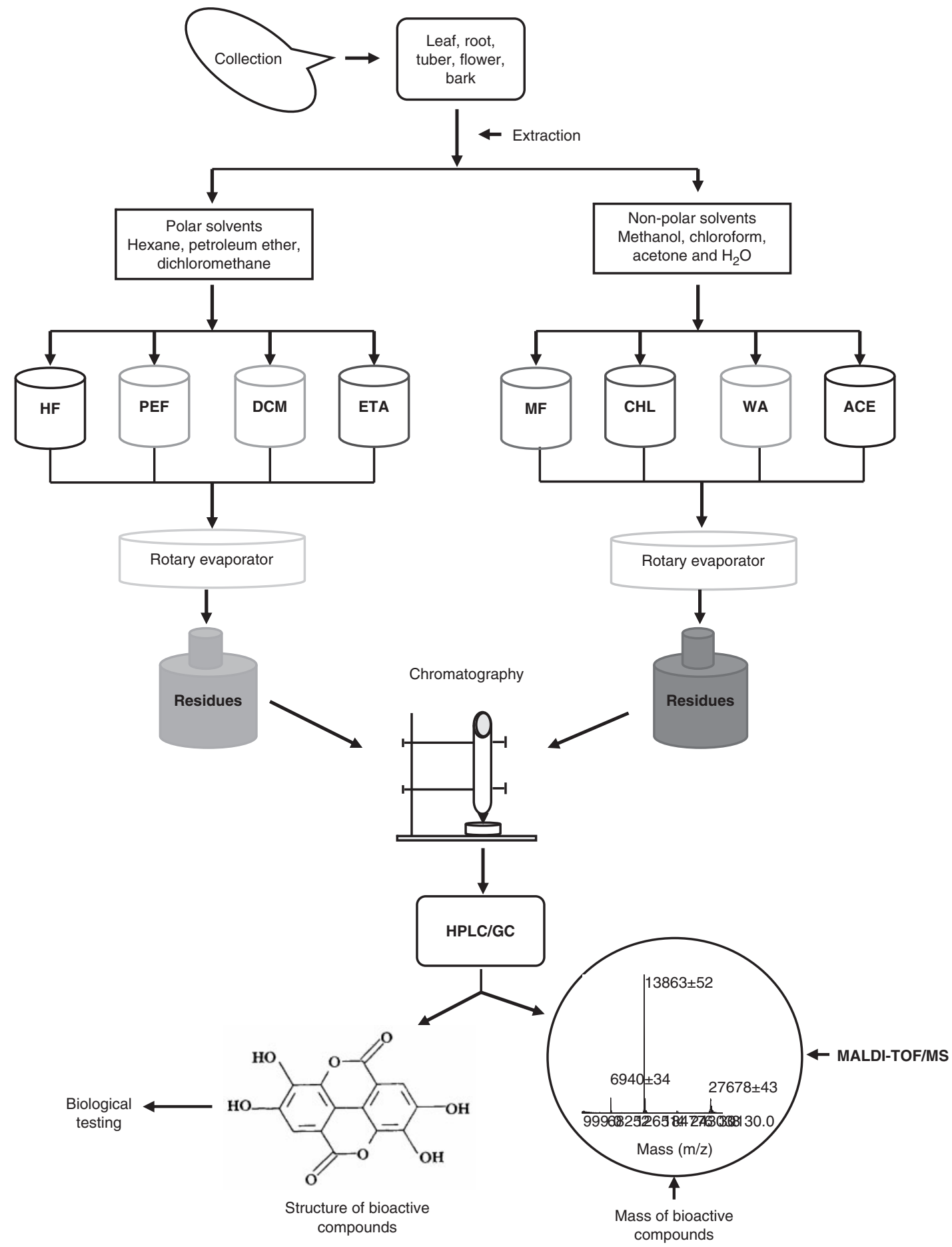

Figure 3. Flow chart for the various sequential protocols involved for the purification, characterization and structural derivation of medicinal plants and their bioactive compounds. Various fractions, i.e. HF: hexane fraction; PEF: petroleum ether fraction; DCM: dichrloromethane fraction; ETA: ethyl acetate fraction; MF: methanol fraction; CHL: chloroform fraction; WA: water and ACE: acetone fraction.

Table 2. Different types of organic solvents are used for the extraction of active compounds

\begin{tabular}{|c|c|c|c|c|c|c|c|}
\hline Acetone & Chloroform & Diethyl ether & Ethanol & Hexane & Methanol & Petroleum ether & Water \\
\hline $\begin{array}{l}\text { Flavonols (80), } \\
\text { alkaloids (33), } \\
\text { naphthol, } \\
\text { glucoside (81), }\end{array}$ & $\begin{array}{l}\text { Terpenoids (82), } \\
\text { flavonoids (83), } \\
\text { steroids (74), } \\
\text { ursolic acid }\end{array}$ & $\begin{array}{l}\text { Alkaloids, } \\
\text { terpenoids, } \\
\text { fatty } \\
\text { acids (84) }\end{array}$ & $\begin{array}{l}\text { Alkaloid (22), tannins, } \\
\text { flavonol, terpenoid, } \\
\text { sesquiterpenes ( } 85) \text {, } \\
\text { sterols, polyphenols, } \\
\text { aporphine } \\
\text { alkaloids (21) }\end{array}$ & $\begin{array}{l}\text { Carvacrol (86), } \\
\text { carvacrol (86) }\end{array}$ & $\begin{array}{l}\text { Terpenoids, } \\
\text { flavonnes, } \\
\text { polyphenols, } \\
\text { tannins (68) }\end{array}$ & $\begin{array}{l}\text { Proanthocyanidin (69), } \\
\text { tannins (70) }\end{array}$ & $\begin{array}{l}\text { Anthrocyanins (87), } \\
\text { tannins (61), } \\
\text { saponins ( } 88), \\
\text { glygosides (74) }\end{array}$ \\
\hline
\end{tabular}




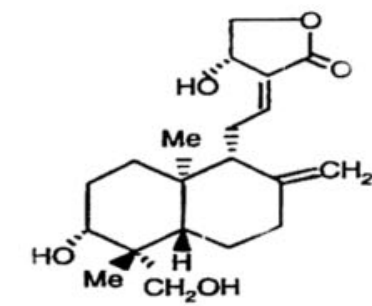

Andrographis paniculata

(Andrographolide)

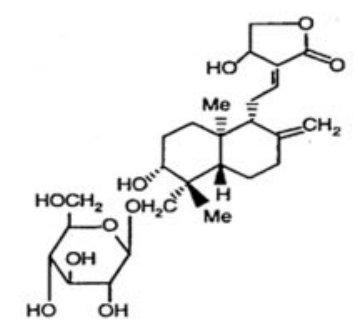

$$
\text { Andrographis paniculata }
$$

(Neoandrographolide)

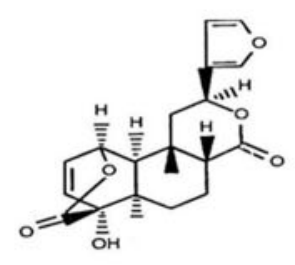

Tinospora cordifolia

(Columbin)

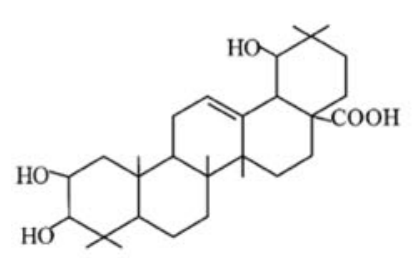

Terminalia arjuna

(Arjunolic acid)

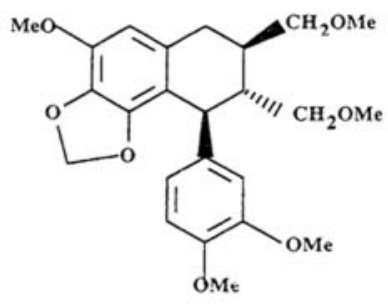

Phyllanthus amarus (Hypophyllanthin)

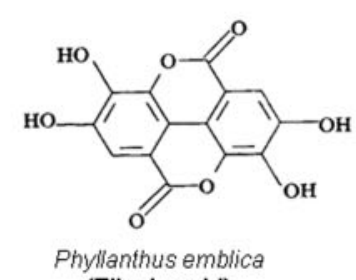

(Ellagic acid)

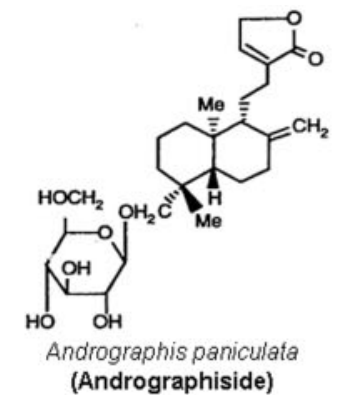

(Andrographiside)

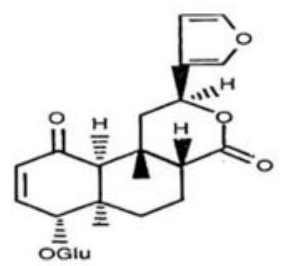

Tinospora cordifolia

(Tinosporaside)

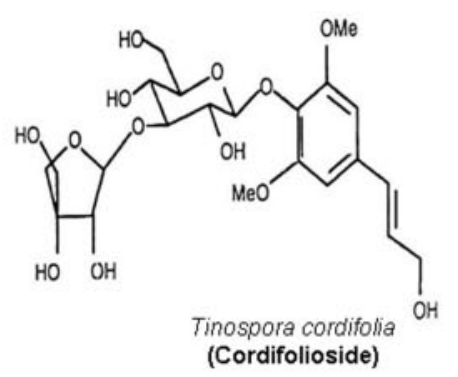

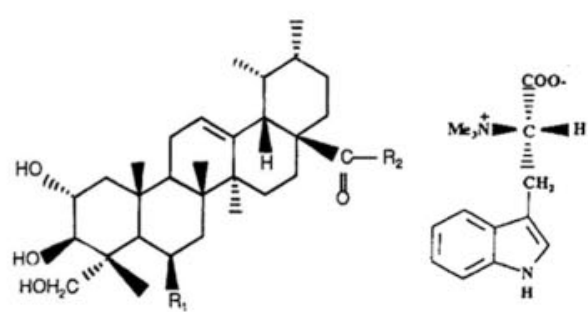

Centella asiatica Centella asiatica (Asiaticoside, $\mathrm{R}=\mathrm{OH}$ ) (Hypaphorine)<smiles>COC[C@H](Cc1ccc(OC)c(OC)c1)[C@H](COC)Cc1ccc(OC)c(OC)c1</smiles>

Phyllanthus amarus (Phyllanthin)

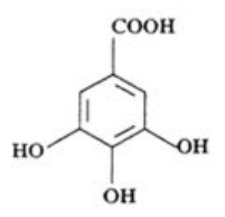

Phyllanthus emblica (Gallic acid)

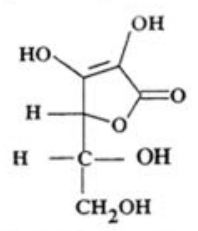

Phyllanthus emblica (Vitamin C)

Figure 4. Structure of common anti-microbial compounds from the popularly used traditional medicinal plants. 
In addition, folklorist, pharmacologist, phytochemists and ethnobotanists are investigating plants for antimicrobials. Several plant-based chemicals have shown potential inhibitory action on a wide range of microorganism in vitro experiment. Although tannins, polyphenols (98), oils (99) and others were identified as the effective component for the bacterial damaging or killing action in the in vitro system, many of these compounds failed in human clinical trails to determine their therapeutic effectiveness.

We concluded that well-designed bioassay-guided isolation and studying anti-microbial effect should be able to complete this task. In the past 20 years, several studies proving the extract or chemicals derived from plant extracts were reported. These studies indicated that extracts contain interesting biopharmaceutical substances (anti-microbials) that have attracted significant scientific attention. More detailed investigation at molecular, cellular levels, suitable animal models and human clinical studies are necessary to elucidate anti-microbial and other biological activities.

\section{Acknowledgements}

The authors would like to thank Dr Bradley G. Stiles, Integrated Toxicology, US Army Medical Research Institute of Infectious Disease, Fort Detrick, Maryland 21702-5011, USA for his evaluation and correction of the manuscript.

\section{References}

1. Kamboj VP. Herbal medicine. Curr Sci 2000;78:35-9.

2. Jain SK. Ethnobotany and research on medicinal plants in India. Ciba Found Symp 1994;185:153-64.

3. Craig WA. Pharmacokinetics/pharmacodynamic parameters: rationale for antibacterial dosing of mice and men. Clin Infect Dis 1998;26:1-12.

4. Pellecure S, Allegrini J, Buochberg S. Huiles essenticlles bactericides et fongicides. Revue del l Institute Pasteur de Lyon 1976;9:135-59.

5. Ali-Shtayeh MS, Yaghmour RMR, Faidi YR, Salem K, Al-Nuri MA. Antimicrobial activity of 20 plants used in folkloric medicine in the Palestinian. J Ethnopharmacol 1998;60:265-71.

6. Valsaraj R, Pushpangadan P, Smitt UW, Adsersen A, Nyman U. Antimicrobial screening of selected medicinal plants from India. J Ethnopharmacol 1997;58:75-83.

7. Smith RA, Calviello CM, Der Marderosian A, Palmer ME. Evaluation of antibacterial activity of belizea plants: an improved method. Pharm Biol 2000;38:25-9.

8. Ahmad I, Beg AZ. Antimicrobial and phytochemical studies on 45 Indian medicinal plants against multi-drug resistant human pathogens. J Ethnopharmacol 2001;74:113-23.

9. Arthur HR. A phytochemical survey of some of plants of North Bornew. J Pharm Pharmacol 1954;6:66-72.

10. Deininger R. Neves aus der Terpenf or schung. Excerpta phytotherapeutika. Lectures of the Medical Congress. Berlin: Firma Klosterfrau, Koln, 1984, 24-31.

11. Martini N, Eloff JN. The preliminary isolation of several antibacterial compounds from Combretum erythrophyllum (Combretaceae). J Ethnopharmacol 1998;62:255-63.

12. Faizi S, Khan RA, Azher S, Khan SA, Tauseef S, Ahmad A. New antimicrobial alkaloids from the roots of Polyalthia longifolia var. pendula. Planta Medica 2003;69:350-5.
13. Geissman TA. Flavonoid compounds, tannins, lignins and related compounds. In: Florkin M, Stotz EH (eds). Pyrrole Pigments, Isoprenoid Compounds and Phenolic Plant Constituents, Vol. 9. New York: Elsevier, 1963, 2653.

14. Feresin GE, Tapia A, Gimenez A, Ravelo AG, Zacchino S, Sortino $\mathrm{M}$, et al. Constituents of the Argentinian medicinal plant Baccharis grisebachii and their antimicrobial activity. J Ethnopharmacol 2003;89:73-80.

15. Abo KA, Adeyemi AA. Seasonal accumulation of anthraquinones in leaves of cultivated Cassia podocarpa Guill et Perr. Afr J Med Sci 2002;31:171-3.

16. Lee-Huang S, Zhang L, Huang PL, Chang YT, Huang PL. AntiHIV activity of olive leaf extract (OLE) and modulation of host cell gene expression by HIV-1 infection and OLE treatment. Biochem Biophys Res Commun 2003;307:1029-37.

17. Chainani-Wu N. Safety and anti-inflammatory activity of curcumin: a component of tumeric (Curcuma longa). J Altern Complement Med 2003;9:161-8.

18. Salgueiro LR, Cavaleiro C, Pinto E, Pina-Vaz C, Rodrigues AG, Palmeira A, et al. Chemical composition and antifungal activity of the essential oil of Origanum virens on Candida species. Planta Medica 2003;69:871-874.

19. Viljoen A, van Vuuren S, Ernst E, Klepser M, Demirci B, Baser H, et al. Osmitopsis asteriscoides (Asteraceae)-the antimicrobial activity and essential oil composition of a Cape-Dutch remedy. J Ethnopharmacol 2003;88:137-43.

20. Martins AP, Salgueiro LR, Goncalves MJ, Proenca da Cunha A, Vila R, Canigueral S. Essential oil composition and antimicrobial activity of Santiria trimera bark. Planta Medica 2003;69:77-9.

21. Gören AC, Zhou BN, Kingston DGI. Cytotoxic and DNA damaging activity of some aporphine alkaloids from Stephania dinklagei. Planta Medica 2003;69:867-8.

22. Olila D, Odyek O, Opuda-Asibo J. Antibacterial and antifungal activities of extracts of Zanthoxylum chalybeum and Warburgia ugandensis, Ugandan medicinal plants. Afr Health Sci 2001;2:66-72.

23. Lau CW, Yao XQ, Chen ZY, Ko WH, Huang Y. Cardiovascular actions of berberine. Cardiovasc Drug Rev 2001;19:234-44.

24. Mahady GB, Pendland SL, Yun GS, Lu ZZ, Stoia A. Ginger (Zingiber officinale Roscoe) and the gingerols inhibit the growth of Cag A + strains of Helicobacter pylori. Anticancer Res 2003;23: 3699-702.

25. Ammon HP. Boswellic acids (components of frankincense) as the active principle in treatment of chronic inflammatory diseases. Wien Med Wochenschr 2001;152:373-8.

26. Narwal S, Balasubrahmanyam A, Sadhna P, Kapoor H, Lodha ML. A systemic resistance inducing antiviral protein with $\mathrm{N}$-glycosidase activity from Bougainvillea xbuttiana leaves. Indian $J$ Exp Biol 2001;39:600-3.

27. Fessenden RJ, Fessenden JS. Organic Chemistry, 2nd edn. Boston, MA: Willard Grant Press, 1982, 139.

28. Wanjala CC, Juma BF, Bojase G, Gashe BA, Majinda RR. Erythrinaline alkaloids and antimicrobial flavonoids from Erythrina latissima. Planta Medica 2002;68:640-2.

29. Ahamd AA, Mahmoud AA, Williams HJ, Scott AI, Reibebspies JH, Mabry TJ. New sesquiterpene $\alpha$-methylene lactones from the Egyptian plants Jasonia candicans. $J$ Nat Prod 1993;56:1276-80.

30. Kariba RM, Houghton PJ, Yenesew A. Antimicrobial activities of a new schizozygane indoline alkaloid from Schizozygia coffaeoides and the revised structure of isoschizogaline. $J$ Nat Prod 2002;65:566-9.

31. Cernakova M, Kostalova D. Antimicrobial activity of berberine-a constituent of Mahonia aquifolium. Folia Microbiol 2002; $47: 375-8$.

32. Iwasa K, Nanba H, Lee DU, Kang SI. Structure-activity relationships of protoberberines having antimicrobial activity. Planta Medica 1998;64:748-51.

33. Ramsewak RS, Nair MG, Strasburg GM, DeWitt DL, Nitiss JL. Biologically active carbazole alkaloids from Murraya koenigii. J Agri Food Chem 1999;47:444-7.

34. Dixon RA, Dey PM, Lamb CJ. Phytoalexins: enzymology and molecular biology. Adv Enzymol 1983;55:1-69. 
35. Srinivas KV, Koteswara Rao Y, Mahender I, Das B, Rama Krishna KV, Hara Kishore K, et al. Flavanoids from Caesalpinia pulcherrima. Phytochemistry 2003;63:789-93.

36. Chiang LC, Cheng HY, Liu MC, Chiang W, Lin CC. In vitro antiherpes simplex viruses and anti-adenoviruses activity of twelve traditionally used medicinal plants in Taiwan. Biol Pharm Bull 2003;26:1600-4.

37. Hu CQ, Chen K, Shi Q, Kilkuskie RE, Cheng YC, Lee KH. AntiAIDS agents, 10 . Acacetin-7-o- $\beta$-D-galactopyranoside, an anti-HIV principle from Chrysanthemum morifolium and a structure-activity correlation with some related flavonoids. J Nat Prod 1994;57:42-51.

38. Hu L, Chen Z. Sesquiterpenoid alcohols from Chrysanthemum morifolium. Phytochemistry 1997;44:1287-90.

39. Tsuchiya H, Sato M, Miyazaki T, Fujiwara S, Tanigaki S, Ohyama $\mathrm{M}$, et al. Comparative study on the antibacterial activity of phytochemical flavanones against methicillin-resistant Staphylococcus aureus. J. Ethnopharmacol 1996;50:27-34.

40. Chaurasia SC, Vyas KK. In vitro effect of some volatile oil against Phytophtora parasitica var. piperina. J Res Indian Med Yoga Homeopath 1997;1:24-6.

41. Manohar V, Ingram C, Gray J. Antifungal activities of origanum oil against. Candida albicans. Mol Cell Biochem 2001;228:111-7.

42. Ali BH, Blunden G. Pharmacological and toxicological properties of Nigella sativa. Phytother Res 2003;17:299-305.

43. Farruque R, Chowdhury R, Sohrab MH, Hasan CM, Rashid MA. Triterpene constituents from the leaves of Melicope indica. Pharmazie 2003;58:518-20.

44. Katerere DR, Gray AI, Nash RJ, Waigh RD. Antimicrobial activity of pentacyclic triterpenes isolated from African Combretaceae. Phytochemistry 2003;63:81-8.

45. Gutierrez-Lugo MT, Singh MP, Maiese WM, Timmermann BN. New antimicrobial cycloartane triterpenes from Acalypha communis. J Nat Prod 2002;65:872-5.

46. Ramesh N, Viswanathan MB, Saraswathy A, Balakrishna K, Brindha P, Lakshmanaperumalsamy P. Phytochemical and antimicrobial studies on Drynaria quercifolia. Fitoterapia 2001;72:934-6.

47. Visen PKS, Shukla B, Patnaik GK. Andrographolide protects rat hepatocytes against paracetamol-induced damage. J Ethnopharmacol 1993:40:131-6.

48. Maquart FX, Bellon G, Gillery P, Wegrowski Y, Borel JP. Stimulation of collagen synthesis in fibroblast cultures by a triterpene extracted from Centella asiatica. Connect Tissue Res 1990;24:107-20.

49. Handa SS. Indian Herbal Phamacopoeia, Vol. I. Mumbai, India: Indian Drug Manufacturer's Association 102-B, 1998, 158-9.

50. Sampson JH, Raman A, Karlsen G, Navsaria H, Leigh IM. In vitro keratinocyte antiproliferant effect of Centella asiatica extract and triterpenoid saponins. Phytomedicine 2001;8:230-5.

51. Price KR, Johnson IT, Fenwick GR. The chemistry and biological significance of saponins in foods and feeding stuff. Crit Rev Food Sci Nutr 1987;26:27-135.

52. Filippone MP, Diaz Ricci J, Mamani de Marchese A, Farias RN, Castagnaro A. Isolation and purification of a 316 Da performed compounds from strawberry (Fragaria ananassa) leaves active against plant pathogens. FEBS Lett 1999;459:115-8.

53. Kiba A, Saitoh H, Nishihara M, Omiya K, Yamamura S C-terminal domain of a hevein-like protein from Wasabia japonica has potent antimicrobial activity. Plant Cell Physiol 2003;44: 296-303.

54. Woldemichael GM, Singh MP, Maiese WM, Timmermann BN. Constituents of antibacterial extract of Caesalpinia paraguariensis Burk. Z Naturforsch 2003;58:70-5.

55. Nizet V, Ohtake $T$, Lauth $\mathrm{X}$, Trowbridge J, Rudisill J, Dorschner RA, et al. Innate antimicrobial peptide protects the skin from invasive bacterial infection. Nature 2001;414:454-7.

56. Zhang Y, Lewis K. Fabatins: new antimicrobial plant peptides. FEMS Microbiol Lett 1997;149:59-64.

57. Sharon N, Ofek I. Mannose specific bacterial surface lectins. In: Mirelman D (ed), Microbial Lectins and Agglutinins. New York: John Wiley \& Sons, Inc., 1986, 55-82.

58. Yasin B, Pang M, Turner JS, Cho Y, Dinh NN, Waring AJ, et al. Evaluation of the inactivation of infectious herpes simplex virus by host-defense peptides. Eur $J$ Clin Microbiol Infect Dis 2001;19:187-94.
59. Brantner A, Males Z, Pepeljnjak S, Antolic A. Antimicrobial activity of Paliurus spina-christi Mill. J Ethnopharmacol 1996; 52:119-22.

60. Okennedy R, Thornes RD, (ed). Coumarins: biology, applications and mode of action. New York: John Wiley \& Sons, Inc., 1997.

61. Berkada B. Preliminary report on warfarin for the treatment of herbes simplex. J Irish Collect Physiol Surg 1978;22 (Suppl 2):56.

62. Puupponen-Pimia R, Nohynek L, Meier C, Kahkonen M, Heinonen M, Hopia A, et al. Antimicrobial properties of phenolic compounds from berries. J Appl Microbiol 2001;90:494-507.

63. Urs NRR, Dunleavy JM. Enhancement of the bactericidal activity of a peroxidase system by phenolic compounds (Xanthomonas phaseoli var. sojensis, soybeans). Phytopathology 1975;65:686-90.

64. Mason TL, Wasserman BP. Inactivation of red beet betaglucan synthase by native oxidized phenolic compounds. Phytochemistry 1987;26:2197-202.

65. Scalbert A. Antimicrobial properties of tannins. Phytochemistry 1991;30:3875-83.

66. Ho KY, Tsai CC, Huang JS, Chen CP, Lin TC, Lin CC. Antimicrobial activity of tannin components from Vaccinium vitisidaea L. J Pharm Pharmacol 2001;53:187-91.

67. Hou AJ, Liu YZ, Yang H, Lin ZW, Sun HD. Hydrolyzable tannins and related polyphenols from Eucalyptus globulus. J Asian Nat Prod Res 2000;2:205-12.

68. Burapadaja S, Bunchoo A. Antimicrobial activity of tannins from Terminalia citrina. Planta Medica 1995;61:365-6.

69. Yoshida T, Hatano T, Ito H. Chemistry and function of vegetable polyphenols with high molecular weights. Biofactors 2000;13:121-5.

70. Reed JD. Nutritional toxicology of tannins and related polyphenols in forage legumes. J Animal Sci 1995;73:1516-28.

71. Somanabandhu A, Nitayangkura S, Mahidol C, Ruchirawat S, Likhitwitayawuid K, Shieh HL, et al. 1H- and 13C-NMR assignments of phyllanthin and hypophyllanthin: lignans that enhance cytotoxic responses with cultured multidrug-resistant cells. J Nat Prod 1993;56:233-9.

72. Fabry W, Okemo P, Ansorg R. Fungistatic and fungicidal activity of east African medicinal plants. Mycoses 1996;39:67-70.

73. Vanka A, Tandon S, Rao SR, Udupa N, Ramkumar P. The effect of indigenous Neem Azadirachta indica [correction of (Adirachta indica)] mouth wash on Streptococcus mutans and lactobacilli growth. Indian J Dent Res 2001;12:133-44.

74. Odebiyi OO, Sofowora EA. Antimicrobial alkaloids from a Nigerian chewing stick (Fagara zanthoxyloides). Planta Medica 1979;36:204-7.

75. Kumar O, Singh B. Effect of Ayurvedic liver stimulants on live weight gain of broilers in North Eastern region. Indian J Animal Res 1992;26:1-5.

76. Satyanarayana P, Subramanyam P, Koteswara RP. Chemical constitutents of Cleistanthus collinus roots. Indian. J Pharm Sci 1984;46:95-6.

77. Dian ZYDC. The Dictionary of Chines Medicine. Shanghai: Shanghai Science and Technique Press, 1997, 2008.

78. Eloff JN. It is possible to use herbarium specimens to screen for antibacterial components in some plants. $J$ Ethnopharmacol 1999;67:355-60.

79. Harbone JB. Phytochemical Methods. A Guide to Modern Techniques of Plant Analysis. London: Chapman and Hall, 1998, $1-302$.

80. Afolayan AJ, Meyer JJM. The antimicrobial activity of 3, 5, 7-trihydroxyflavon isolated from the shoots of Helichrysum aureonitens. J Ethnopharmacol 1997;57:177-81.

81. Seca AM, Silva AM, Silvestre AJ, Cavaleiro JA, Domingues FM, Pascoal-Neto C. Lignanamides and other phenolic constituents from the bark of kenaf (Hibiscus cannabinus). Phytochemistry 2001;58:1219-23.

82. Ayafor JF, Tchuendem HK, Nyasse B. Novel bioactive diterpenoids from Aframomum aulacocarpos. J Nat Prod 1994;57:917-23.

83. Perrett S, Whitefield PJ, Sanderson L, Bartlett A. The plant molluscide Millettia thonningii (Leguminosae) as a topical antischistosomal agent. J Ethnopharmacol 1995;47:49-54.

84. Perumal Samy R, Ignacimuthu S, Sen A. Screening of thirtyfour Indian medicinal plants for antibacterial properties. J Ethnopharmacol 1998;62:173-82. 
85. Zhang Z, ElSohly HN, Jacob MR, Pasco DS, Walker LA, Clark AM. New sesquiterpenoids from the root of Guatteria multivenia. J Nat Prod 2002;65:856-9.

86. Kunle O, Okogun J, Egamana E, Emojevwe E, Shok M. Antimicrobial activity of various extracts and carvacrol from Lippia multiflora leaf extract. Phytomedicine 2003;10:59-61.

87. Kaul TN, Middletown Jr, Ogra PL. Antiviral effect of flavonoids on human viruses. J Med Virol 1985;15:71-9.

88. De Pasquale R, Germano MP, Keita A, Sanogo R, Iauk L. Antiulcer activity of. Pteleopsis subersa. $J$ Ethnopharmacol 1995;47:55-8.

89. Hirasawa M, Takada K. Multiple effects of green tea catechin on the antifungal activity of antimycotics against Candida albicans. J Antimicrob Chemother 2003;46:1-5.

90. Ficker C, Smith ML, Akpagana K, Gbeassor M, Zhang J, Durst T, et al. Bioassay-guided isolation and identification of antifungal compounds from ginger. Phytother Res 2003;17:897-902.

91. Suzutani T, Ogasawara M, Yoshida I, Azuma M, Knox YM. Antiherpesvirus activity of an extract of Ribes nigrum L. Phytother Res 2003;17:609-13.

92. Camacho MR, Kirby GC, Warhurst DC, Croft SL, Phillipson JD. Oxoaporphine alkaloids and quinones from Stephania dinklagei and evaluation of their antiprotozoal activities. Planta Medica 2000;66:478-80.
93. John D. One hundred useful raw drugs of the Kani tribes of Trivandrum forest division, Kerala. Int $J$ Crude Drug Res 1984;22:17-39.

94. Puspangadan P, Atal CK. Ethnomedico-botanical investigation in Kerala I. Some primitive tribals of Western Ghats and their herbal medicine. J Ethnopharmacol 1984;11:59-77.

95. Dev S. Ethnotherapeutics and modern drug development: The potential of Ayurveda. Curr Sci 1997;73:909-28.

96. Vogel HG. Similarities between various systems of traditional medicine. Considerations for the future of ethnopharmacology. J Ethnopharmacol 1991;35:179-90.

97. Khan M, Schneider B, Wassilew SW, Splanemann V. Experimental study of the effect of raw materials of the neem tree and neem extracts on dermatophytes, yeasts and molds. Z Hautkr 1988;63:499-502.

98. Biradar YS, Jagatap S, Khandelwal KR, Singhania SS. Exploring of antimicrobial activity of Triphala Mashi - an Ayurvedic formulation. Evid Based Complement Alternat Med 2008;5:107-13.

99. Vukovic N, Milosevic T, Sukdolak S, Solujic S. Antimicrobial activities of essential oil and methanol extract of. Teucrium montanum. Evid Based Complement Alternat Med 2007;4:17-20.

Received April 12, 2007; accepted April 18, 2008 


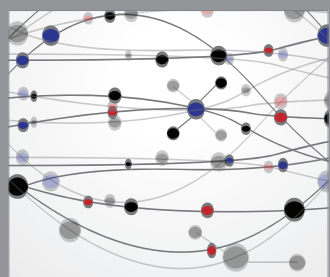

The Scientific World Journal
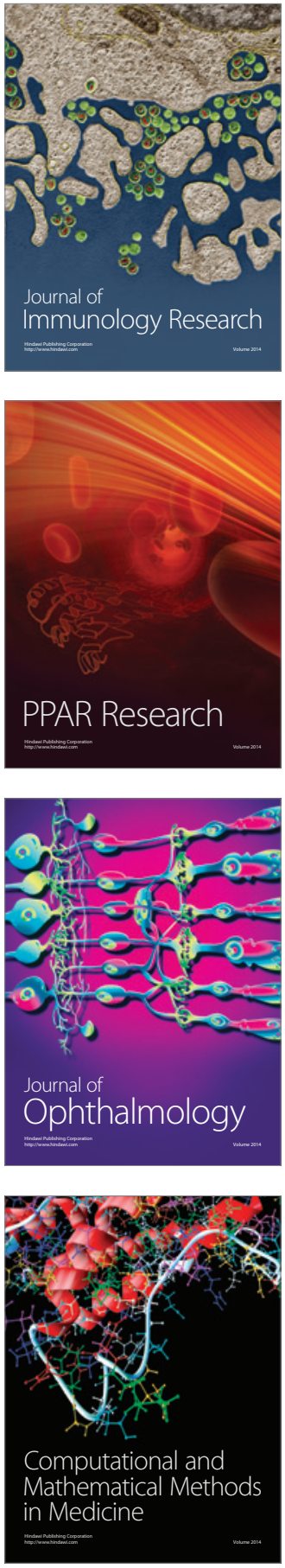

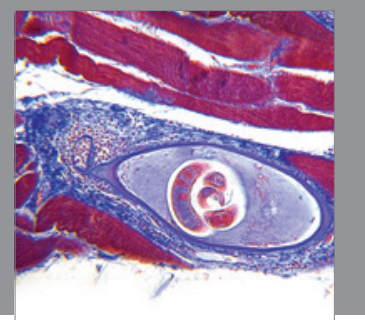

Gastroenterology

Research and Practice
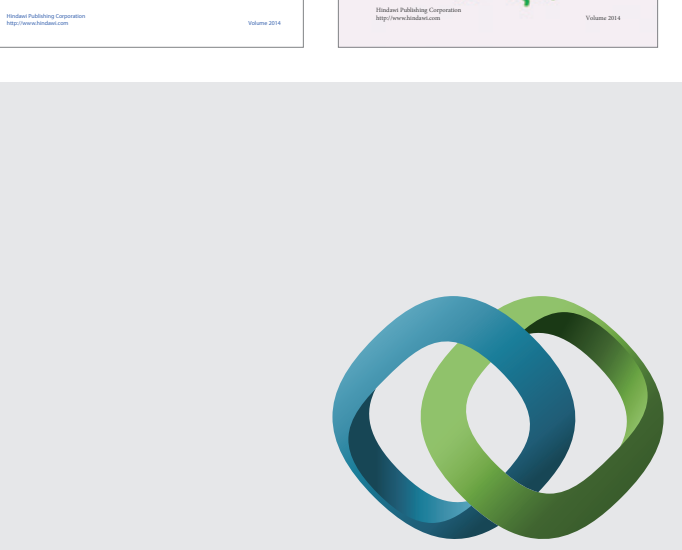

\section{Hindawi}

Submit your manuscripts at

http://www.hindawi.com
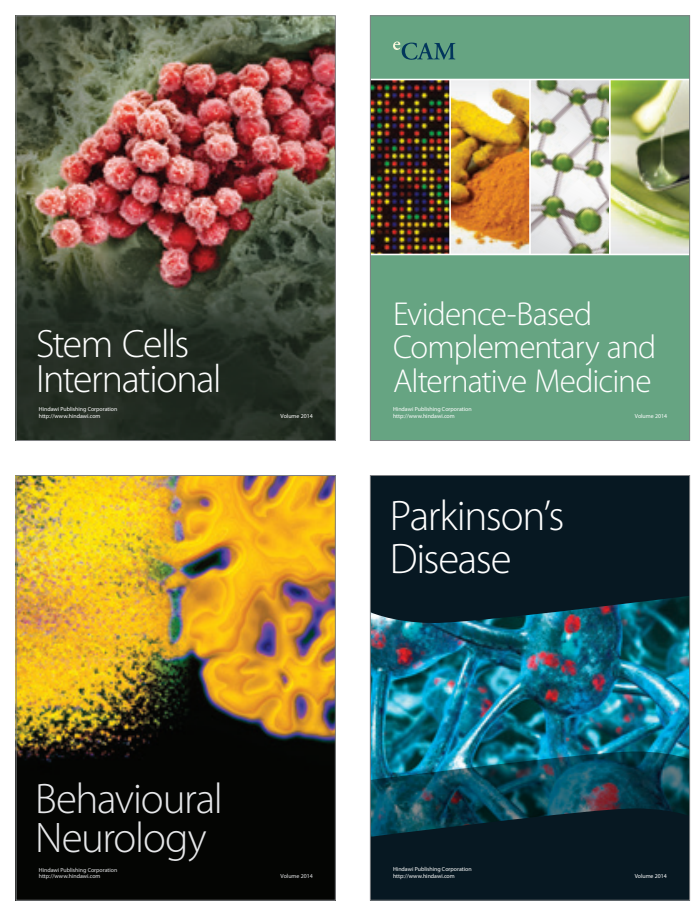

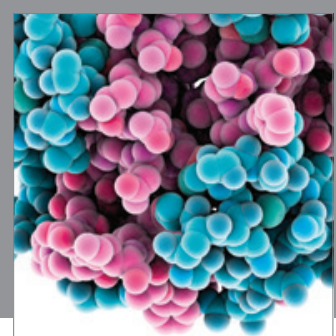

Journal of
Diabetes Research

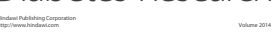

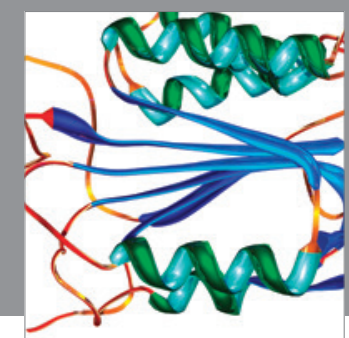

Disease Markers
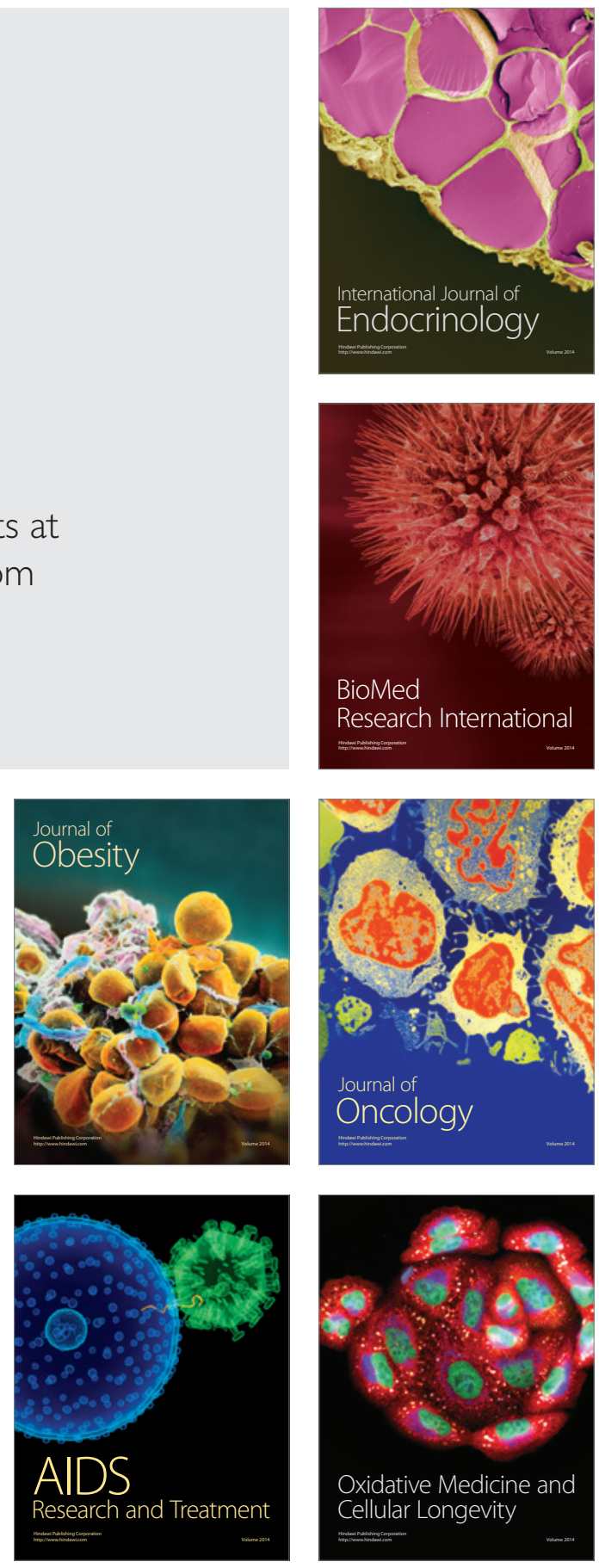